\title{
ISU-ISU KONTEMPORER HUKUM BISNIS SYARIAH (MONOPOLI DALAM BISNIS SYARIAH)
}

\author{
Dadi Permana Putra \\ S2 Hukum Bisnis Syariah UIN Sunan Kalijaga Yogyakarta \\ Email: dadi.p51@yahoo.com
}

\begin{abstract}
ABSTRAK
Monopoli dan oligopoli, monopsosi, posisi dominan, dan berbagai bentuk persaingan tidak sehat lainya dalam dunia perdagangan. Sejatinya pasar merupakan elemen ekonomi yang dapat mewujudkan kemaslahatan dan kesejateraan hidup manusia. Islam melarang persaingan tidak sehat dan menutup semua jalan yang menuju ke arahnya. Barang dan jasa yang menjadi kebutuhan masyarakat tidak pernah dibenarkan untuk dimonopoli. Dalam pandangan Islam monopoli merupakan sesuatu yang sah. Yang tidak diperbolehkan dalam Islam adalah perilaku monopolis yang dapat merugikan masyarakat.
\end{abstract}

Kata kunci: monopoli, ihtikar, hukum bisnis syariah.

\begin{abstract}
Monopoly and oligopoly, monopsy, dominant position, and various other forms of unfair competition in the world of commerce. Indeed the market is an economic element that can realize the benefit and welfare of human life. Islam forbids unfair competition and closes all roads leading to it. Goods and services that are community needs are never justified to be monopolized. In the view of Islam monopoly is something that is legal. What is not permitted in Islam is monopolistic behavior that can harm society.
\end{abstract}

Keywords: monopoly, ihtikar, sharia business law

\section{Pendahuluan}

Persaingan yang merupakan ciri lain kapitalisme, membawa kehancuran bagi perusahanan kecil. Pengakuan atas keberadaan monopoli akan mendorong terjadinya marget beberapa bisnis kecil menjadi satu sehingga menjadi onopoli atau kartel. Monopoli membunuh persaingan bebas, menyebabkan inflasi dan akhirnya menyebabkan terjadinya penganguran. Baik pekerja maupun konsumen sama-sama tertindas dalam keadaan seperti itu. ${ }^{1}$

Di Indonesia praktek monopoli sudah ada sejak zaman penjajahan. Dalam masa 200 tahun pertama penjajahan dilakukan oleh Vereenigde Oost-Indische Compagnie (VOC), yang memperoleh monopoli dari pemerintah belanda untuk berdagang di Nusantara Indonesia dan diberi hak mengadakan berbagai macam perjanjian dengan

${ }^{1}$ Chaudhy Muhammad Sharif, Sistem Ekonomi Islam: Prinsip Dasar (Cet. 3, Ed. 1; Jakarta: Kencana, 2016), h. 358-359. 


\section{Tahkím}

Vol. XIV, No. 2, Desember 2018

raja-raja Indonesia atsa nama Pemerintah Republik tujuh provinsi. Ia diperlengkapi dengan armada perang yang akan melindugi monopolinya yang di paksa kepada rakyat dan raja-raja Indonesia. ${ }^{2}$

Kebangkitan Islam yang sedang berlangsung di hampir semua negara muslim telah menciptakan kebutuhan akan sebuah gambaran integratif dan jelas dari program yang akan ditawarkan untuk islam utuk mewujudkan kebahagiaan yang di cita-citakan dan menjelaskan berbagai persoalan yang kini sedang dihadapi umat manusia terutama di bidang ekonomi. ${ }^{3}$

Monopoli dan oligopoli, monopsosi, posisi dominan, dan berbagai bentuk persaingan tidak sehat lainya dalam dunia perdagangan, merupakan suatu bentuk nyata atas defisiasi-defisiasi pasar. ${ }^{4}$ Pasar merupakan wadah yang dapat mempertemukan pihak penjual dan pembeli untuk melakukan transaksi atas barang dan jasa. Dalam perekonomian, pasar mempunyai peranan yang penting untuk mengerakan roda kehidupan ekonomi masyarakat. Sejatinya pasar merupakan elemen ekonomi yang dapat mewujudkan kemaslahatan dan kesejateraan hidup manusia. ${ }^{5}$ Islam melarang persaingan tidak sehat dan menutup semua jalan yang menuju ke arahnya. Barang dan jasa yang menjadi kebutuhan masyarakat tidak pernah dibenarkan untuk dimonopoli. ${ }^{6}$

Makalah ini bertujuan untuk membahas monopoli dan ihtikar dalam Islam, menganalisis praktek monopoli dalam pansa pasar dan menganalisis monopoli dalam hukum bisnis syariah.

\section{Pengertian Monopoli}

Monopoli secara harfiah berarti di pasar hanya ada satu penjual. Frank Fisher menjelaskan kekuatan monopoli sebagai the ability to act in unconstained way (kemampuan bertindak dalam menetukan harga dengan caranya sendiri), sedangkan Besanko, dkk., menjelaskan monopoli sebagai penjual yang menghadapi little or no compatition (kecil atau tidak ada persaingan). ${ }^{7}$

Menurut Kamus Umum Indonesia, monopoli, berarti; 1. perdagangan barang tertentu yang hanya boleh dilakukan oleh satu orang, atau perusahaan atau oleh

${ }^{2}$ Muhammad Hatta, Satu Abad Bung Hata: Demokrasi Kita, Bebas Aktif, Ekonomi Masa Depan, (Jakarta: UI Press, 2006), h. 203.

${ }^{3}$ M. Umer Chapra, Islam Dan Tantangan Ekonomi (Cet. 1; Jakarta: Gema Insani Press, 2000), h. 1.

${ }^{4}$ Agus Triyanta, Hukum Ekonomi Islam: Dari Politik Hukum Ekonomi Islam Sampai Pranata Ekonomi Syariah (Cet. 1; Yogyakarta: FH UII Press, 2012), h. 144.

${ }^{5}$ Rozalinda, Ekonomi Islam: Teori dan Aplikasinya Pada Aktivitas Ekonomi, (Cet. 3, ed. 1; Jakarta: Rajawali Pers, 2016), h. 143.

${ }^{6}$ Chaudhy Muhammad Sharif, op.cit., h. 359.

${ }^{7}$ Adiwarman A. Karim, Ekonomi Mikro Islam, (Cet. 4, Ed. 3; Jakarta: Rajawali Pers, 2011), h. 173. 


\section{Tahkím}

Vol. XIV, No. 2, Desember 2018

pemerintah; 2. hak tunggal yang diberikan kepada seoranga atau segolongan orang. ${ }^{8}$ Sedangkan dalam Kamus Besar Ekonomi dijelaskan, monopoli adalah jenis struktur pasar yang di dalamnya terdapat satu kekuatan penawaran sehingga monopoli tersebut bisa menjalankan politik harga dan mentukan jumlah barang yang harus di pasarkan.

M. Umar Burhan dalam bukunya Konsep Dasar Teori Ekonomi Mikro menjelaskan bahwa monopoli adalah bentuk pasar di mana hanya ada satu orang penjual di pasar. ${ }^{10}$ Sedangkan M. Abd Mannan menjelaskan bahwa, Monopoli mendambakan pemusatan suplai dalam suatu negara, maka soal ekploitasi banyak sekali dihubungkan dengan gagasan monopoli. ${ }^{11}$ Yusuf Al-Qaradhawi berpendapat bahwa monopoli adalah menahan barang dari perputaran di pasar sehingga harganya naik. $^{12}$

Dalam Islam keberadaan satu penjual di pasar, atau tidak adanya pesaing, atau kecilnya persaingan di pasar, bukanlah sesuatu yang terlarang. Siapapun boleh berdagang tampa peduli apakah dia satu-satunya penjual atau ada penjual lain. Jadi monopoli dalam artian harfiah, boleh saja. Akan tetapi, siapapun dia tidak boleh melalukan ihtikar. ${ }^{13}$ Dalam Jurnal Ahkam Hukum Islam dikatakan juga, dalam ekonomi Islam siapa pun boleh berbisnis. Namun demikian, tidak boleh melakukan ihtikar, yaitu mengambi keuntungan di atas keuntungan normal dengan menjual lebih sedikit barang untuk harga yang lebih tinggi. ${ }^{14}$

Dalam bisnis syariah monopoli di kaitkan dengan iktikar. Iktikar secara bahasa berarti:

$$
\text { الا حتكار لخة : احتباس الثيء انتظار الغلائه }
$$

'al-ihtikar secara bahasa berarti menahan sesuatu untuk menunggu harga naik.'

Ihtikar berarti juga al-jam'u wa al-imsak, mengumpulkan (barang-barang) dan menahan. Ihtikar artinya zalim (aniaya) dan merusak pergaulan. Menahan (menimbun) barang-barang kebutuhan pokok manusia untuk dapat meraih keuntungan dengan menaikan harganya. Upaya menimbun barang dagangan untuk menunggu melonjaknya harga. Adapun pengertian ihtikar dalam tinjauan fikih adalah penahan atau penimbunan atas suatu barang dagangan dengan tujuan untuk di jual kembali pada

\footnotetext{
${ }^{8}$ J.S Badudu dan Muhammad Zain Sultan, Kamus Umum Bahasa Indonesi (Jakarta: Pustaka Sinar Harapan, 1994), h. 907.

${ }^{9}$ Winarno Sigit dan Ismaya Sujana, Kamus Besar Ekonomi,(Cet. 3; Bandung: Pustaka Grafik, 2010), h. 319.

${ }^{10}$ M. Umar Burhan, Konsep Dasar Teori Ekonomi Mikro: Disertai Contoh-Contoh Soal dan Penyelesainanya, (Cet. 1; Malang: Badan Penerbit Fakultas Ekonomi Brawijaya, 2006), h. 189. 1995), h. 291.

${ }^{11}$ M. Abdul Mannan, Teori dan Praktek Ekonomi Islam, (Yogyakarta: PT. Dana Bakti Wakaf,

${ }^{12}$ Yusuf Al-Qaradhawi, Norma dan Etika Ekonomi Islam (Cet. 1, Jakarta: Gema Insani Press, 1997), h. 189.

${ }^{13}$ Adiwarma A. Karim, op.cit, h. 173-174.

${ }^{14}$ Mauludi Ali, "Pasar Bebas Dalam Perspektif Ekonomi Islam," Jurnal Ahkam Hukum Islam,
} Vol. 1, No. 1, 2013, h.. 88 . 


\section{Tahblím}

Vol. XIV, No. 2, Desember 2018

saat harga naik. ${ }^{15}$ Dalam hukum bisnis syariah, praktek penimbunan hukumnya diharamkan, karena menghalangi masyarakat untuk mendapatkan barang-barang kebutuhan. Pada konteks sekarang, ihtikar meliputi praktek monopoli dalam dunia perdagangan. ${ }^{16}$

Ibnu Khaldun dalam bukunya Mukaddimah menjelaskan bahwa monopoli dan penimbunan komoditi untuk di keluarkan saat kondisi pasar sangat membutuhkan sehinggah harga jualnya menjadi mahal adalah tindakkan tercela. ${ }^{17}$ Ibnu Taimiyah mengemukakan pelaku ihtikar atau muhtakir sengaja membeli makanan yang dibutuhkan manusia, kemudia ia tahan untuk menunggu naiknya harga barang tersebut. Iman As-Syaukani mendefenisikan ihtikar adalah "menahan barang dari perdagangan."

Sedangkan Sayyid Sabiq menyatakan ihtikar adalah sebagai membeli suatu barang dan menyimpanya agar barang tersebut berkurang di masyarakat harganya meningkat yang mengakibatkan manusia medapatkan kesulitan akibat kelangkaan dan malahnya harga barangan tersebut. ${ }^{18}$

Dalam Fikih Ekonomi Umar Bin Al-Khathab dijelaskan bahwa penimbunan barang adalah halagan terbesar dalam pengaturan persaingan dalam pasar islam. Hal tersebut dikarenakan pengaruhnya jumlah barang yang tersedia dari barang yang ditimbun, dimana beberapa pedagang memilih untuk menahan barang daganganya dan tidak menjualnya karena menunggu naiknya harga. Perilaku ini mempunyai pengaruh negatif dalam fluktuasi kemampuan dan persediaan barang. ${ }^{19}$

Definisi-definisi di atas mempunyai pengertian yang sama, yaitu ada upaya dari seseorang menimbun barang pada saat barang itu harganya murah untuk menunggu harga akan naik. Misalnya, pedagang gula pasir di awal bulan Ramadhan tidak mau menjual barang dagangannya, karena mengetahui bahwa pada minggu terakhir bulan Ramadhan masyarakat sangat membutuhkan gula untuk menghadapi lebaran. Dengan menipisnya stok di pasaran, harga gula pasti akan naik. Ketika itulah para pedagang gula menjual gulanya., sehingga pedagang tersebut mendapat keuntungan yang berlipat ganda. $^{20}$

Lawan dari monopoli adalah oligopoli. Adiwarman A. Karim menjelaskan bahwa oligopoli secara harfiah berarti ada beberapa penjual di pasar. Boleh dikatakan oligopoli merupakan pertengahan dari monopoly dan monopolistic competition. Dalam monopoly, penjual dapat menentukan harga tampa harus khawatir reaksi penjual lain.

\footnotetext{
${ }^{15}$ Rozalinda, Fikih Ekonomi Syariah: Prinsip dan Implementasinya Pada Sektor Keuangan Syariah, (Cet. 2, Ed. 1; Jakarta: Rajawali Pers, 2017), h. 351.

${ }^{16}$ Burhanuddin S., Hukum Bisnis Syariah, (Cet. I, Yogyakarta: UII Press, 2011), h. 234.

${ }^{17}$ Ibnu Khaldun, Mukaddimah: Sebuah Karya Mega-Fenomenal dari Cendikiawan Muslim Abad Pertengaha, (Cet. 1; Jakarta: Pustaka Al-Kausar, 2011), h. 718.

${ }^{18}$ Rozalinda, op.cit., h. 352-374.

${ }^{19}$ Jaribah Bin Ahmad Al-Haritsi, Fikih Umar Bin Al-Khathab, (Cet. 1; Jakarta Timur: Pustaka Al-Kautsar, 2006), h. 603.

${ }^{20}$ Adiwarman A. Karim A. op.cit., h. 201-202.
} 


\section{Tahkím}

Vol. XIV, No. 2, Desember 2018

Dalam monopolistic compotition, penjual hanya dapat menentukan pada kisaran tertentu karena bila ia menjual di luaran kisaran tersebut, penjual lain yang menjual barang yang mirip akan merebut pelanggannya.

Sedangakan menurut Burhanuddin S., pasar oligopoli adalah pasar dimana penawaran satu jenis barang dikuasai oleh beberapa perusahaan. Praktek oligopoli umumnya dilakukan sebagai salah satu upaya untuk menahan perusahaan potensial masuk kedalam pasar, sehingga menyebabkan kompetisi harga diantara pelaku usaha yang melakukan praktek oligipoli menjadi tidak ada. ${ }^{21}$

\section{Dasar Hukum Monopoli}

Para ahli fikih menyatakan ihtikar atau monopoli adalah perbuatan terlarang. Dasar hukum pelarangan ini adalah kandungan Al-qur'an yang menyatakan bahwa setiap perbuatan aniaya, termasuk diladam ihtikar, diharamkan oleh agama, yang ditunjukkan dalam QS al-Baqarah: 279

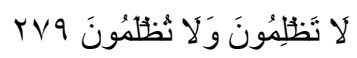

'Kamu tidak menganiaya dan tidak (pula) dianiaya.'

Dalam tafsinya ath-thabari menjelaskan bahwa: Abu Ja'far berkata: maksud Allah

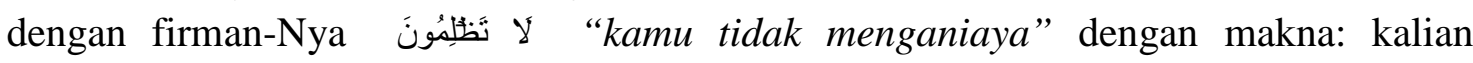
mengambil pokok harata kalian yang kalian miliki sebelum diribakan kepada orangorang yang berhutang kepada kalain tampa mengambil keuntungannya yang kalaian tambahkan sebagai riba dari mereka sehingga kalian mengambil dari mereka apa yang bukan hak kalaian, atau sebelumnya bukan menjadi hak kalian. وَلَ ثُخلمُونَ "dan tidak pula dianiaya" Allah ta'ala Berfirman: orang yeng berhutang yang kalian beri buakan riba tapi karena penambahan tempo sehingga sehingga mengurangi hak kalian atasnya, lalu kalian menahannya, karena tambahan modal kalian bukan menjadi hak kalian, telah berbuat zalim kepada kalian.

Ahli tafsir seperti Ibn Zaid senada dengan pendapat di atas, berdasarkan riwayat-riwayat sebagai berikut: Yunus menceritakan kepadaku, ia berkata: Ibnu Wahab memberitahukan kepada kami, ia berkata: Ibnu Ziad berkata tentang firman

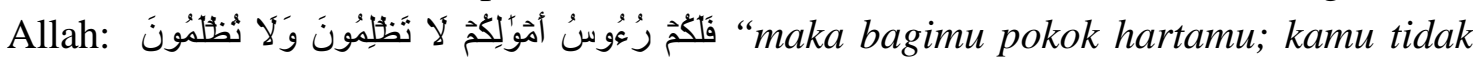
menganiaya dan tidak pula dianiaya" ia berkata: "janganlah kalian mengurangi haryta kalian dan janganlah mengambil secara bathil yang tidak halal bagi kalian."22

Ibnu Abbas r.a. mengatakan, bahwa kelak pada hari kiamat dikatakan kepada pelaku riba, "ambilah senatamu untuk berperang." Lalu Ibnu Abbas membaca ayat 279: "maka jika kamu tidak mengerjakan (meninggalkan sisa riba), maka ketahuilah, Allah dan Rasul-Nya akan memerangimu." Karena itu terhadap orang yang melakukan riba hendaklah dinasehati oleh pemipin atau kaum muslimin supaya bertaubat.

${ }^{21}$ Adiwarman A. Karim A. op.cit., h. 201-202.

${ }^{22}$ Al-Thabari, Tafsir Ath-Thabari, Surah Al-Baqarah, Jilid 4, (Cet. 1, Jakarta: Pustaka Azzam, 20008), h. 748-749. 


\section{Tahblím}

Vol. XIV, No. 2, Desember 2018

Qatada berkata, "Allah mengancam dengan hukuman bunuh, dan menjadikan mereka sebagai simbol kejahatan di mana meraka berada. Karena itu berhati-hatilah kalian dari pergaulan mereka. Sesungguhnya Allah telah meluaskan mata pencarian yang halal, jangan sampai karena kemiskinan kalian terpaksa berbuat maksiat."23

Selain Al-Qur'an yang melarang ada pula hadis yang melarangnya antara lain:

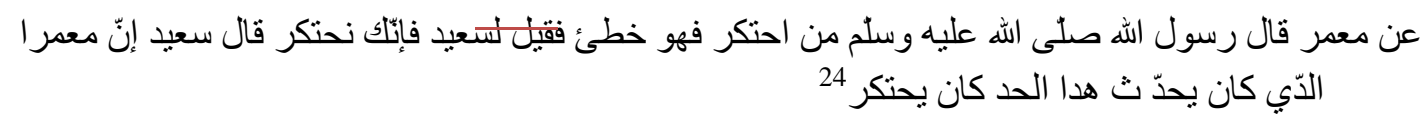

'Diriwayatkan oleh Ma'mar Bin Abdullah, dia berkata, Rasulullah saw bersabda: barang siapa yang menimbun barang dagangan (agar ketika sudah langka barang dagangan itu dia bisa menaikkan harganya) dan ini adalah perbuatan yang salah (dosa). Kemudian hal ini dikatakan kepada Sa'ad bin Al-Musayyib: sesungguhnya kamu termasuk yang menimbun barang dagangan. Sa'id mengatakan: sesungguhnya Ma'mar adalah orang yang menceritakan hal ini dan dia sendiri termasuk yang menimbun.

Lafad حطئ dalam hadis di atas menurut ahli bahasa memiliki arti seseorang yang berbuat durhaka dan melakukan perbuatan dosa. Berarti orang yang berbuat dosa dan berbuat maksiat merupakan suatu indikasi yang menunjukan bahwa tuntutan untuk meninggalkan tersebut bermakna tegas (keras). Dengan demikian, perbuatan ihtikar termasuk perbuatan yang di haramkan.

Orang yang melakukan ihtikar (penimbunan barang dagangannya) dengan sengaja untuk menunda penjualan barang (dagang) itu ke pasar, bertujuan untuk mendapatkan kenaikan harga barang, dengan memanfaatkan kelangkaan barang (dagangan) dan kebutuhan konsumen (pembeli), dianggap bersalah (berdosa karena tindakannya). ${ }^{25}$ Suatu ketika harga bahan-bahan makanan melambung tinggi di masa Rasulullah saw. sehingga beberapa sahabat mengadu kepada Rasulullah saw meminta untuk beliau mematok harga . maka Nabi saw bersabda:

انّ الهه هو المسّر القابض الباسط الرّارق، و إنّي لأرخو أن ألقى الله وليس أحد منكم بطالبنى بمظلمة فى دم و لامال

'Sesungguhnya hanya allah yang menetapkan harga, Dia yang menahan, Dia yang menghamparkan dan Dia yang memberi rezeki. Sesungguhnya aku berharap dapat memenuhu Allah (diakhirat) tampa seorangpun menuntut balasan kezaliman yang aku lakukan terhadap harta dan jiwa (karena menzalimi pedagang dengan menetapkan harga yang tentunya mengurangi laba untuk mereka).' (HR. Abu Daud, dinyatakan shahih oleh Al-Albani).

Sebagaimana Rasulullah saw tidak mau menzalimi para pedagang dengan menurunkan laba yang seharusnya mereka dapatkan dari kenaiikan harga, maka beliau juga tidak mau para pedagan menzalimi khalayak ramai dengan cara ihtikar sehingga harga barang-barang pokok naik tinggi yang berakibat kepada menurunnya daya beli

\footnotetext{
${ }^{23}$ Ibnu Katsir, Terjemahan Singkat Tafsir Ibu Kasir, (Ed. Revisi; Surabaya: PT. Bina Ilmu, 2012), h. 549.

${ }^{24}$ Imam Al-Mundziri, Ringkasan Shahih Muslim, (Cet. 4; Bandung: Jabal, 2016).

${ }^{25}$ Rozalinda, op.cit., h. 355-356.
} 


\section{Tahkím}

Vol. XIV, No. 2, Desember 2018

uang yang berada di tangan masyarakat banyak. Sesungguhnya ihtikat adalah tindakan kezalimaan yang nyata. ${ }^{26}$

Monopoli dan Persaingan Tidak Sehat juga diatur dalam Undang-Undang RI Nomor 5 Tahun 1999. Dalam undang-undang tersebut dinyatakan bahwa monopoli adalah penguasaan atas produksi dan atau pemasaran barang dan atau atas pengunaan jasa tertentu oleh satu pelaku usaha atau satu kelompok pelaku usaha. Praktek monopoli adalah pemusatan kekuatan ekonomi oleh satu atau lebih pelaku usaha yang mengakibatkan dikuasainya produksi dan atau pemasaran atas barang dan atau jasa tertentu sehingga menimbulkan persaingan usaha tidak sehat dan dapat merugikan kepentingan umum. ${ }^{27}$

\section{Jenis Barang dan Waktu Pengharaman Monopoli}

Para fuqaha berbeda pendapat tentang dua masalah:

\section{Jenis barang yang dimonopoli}

Sebagian fuqaha melarang monopoli hanya terhadap bahan makanan. Menurut Al-Ghazali, barang-barang yang bukan makanan atau penunjang bahan makanan seperti obat, ramuan obat-obatan, kunyit dan lain-lain tidak dilarang. Adapun bahanbahan penunjang bahan makanan seperti daging, buah-buahan masih dalam pertimbangan. Di antara ulama ada yang menolak pengharaman monopoli samin, madu, keju, minyak.

Tidak seperti pada masa lalu, obat-obatan pada masa kini adalah bagian primer dari kehidupan manusia. Begitu juga dengan pakaian dan selainya. Kebutuhan manusia terus berkembang masa demi masa. Betapa banyak kita jumpai barang yang dikategorikan sekunder atau pelengkap pada zaman dulu menjadi primer dan kebutuhan pokok pada saat ini. Imam Ad-Duraini menyatakan bahwa, ihtikar tidak dibatasi pada makanan saja. Ihtikar dapat berlaku pada makanan, pakaian manfaat dan jasa. Imam Ad-Duraini melihat, pihak pekerja yang memboikot pihak majikan juga dianggap sebagai ihtikar.

2. Waktu diharamkannya praktek monopoli

Ulama yang mengharamkan praktek monopoli pada segala waktu, tanpa membedakan masa paceklik dengan masa surplus pangan, berdasarkan sifat umum larangan terhadap monopoli dari hadis yang dikutip. Inilah pendapat golongan salaf. Al-Ghazali mengatakan bahwa larangan terhadap monopoli berlaku pada masa krisis pangan. Ketika itu, manusia sangat membutuhkan makanan yang jika mereka tidak segerah mendapatkannya, akan timbul bencana. Adapun pada waktu surplus, ketika

\footnotetext{
${ }^{26}$ Erwandi Tarmizi, Harta Haram Muamalat Kontemporer, (Cet. 16; Bogor: Berkat Mulia Insani, 2017), h. 188.

${ }^{27}$ T.S.C Kansil. dan Kansil Christine S.T., Pokok-Pokok Pengetahuan Hukum Dagang Indonesia,(Cet. 3; Jakarta: Sinar Grafik, 2006), h. 188.
} 


\section{Tahkím}

Vol. XIV, No. 2, Desember 2018

makanan melimpah dan manusia tidak membutuhkan kecuali sedikit, maka monopoli tidak akan menimbulkan ganguan. ${ }^{28}$

\section{Analisis Monopoli}

Monopoli mengacu pada penguasaan terhadap penawaran dan harga. Monopoli sempurna terlihat bila sebuah penawaran tunggal memproduksi suatu komoditi yang tidak di keluarkan oleh perusahaan lainhya. Dengan demikian elastisitas permintaan silang sebuah permintaan monopoli adalah kecil. Perbedaan monopoli dengan bentuk persaingan lain adalah bahwa monopoli dapat menetapkan harga pasar untuk hasil produksinya, karena ia merupakan produsen tunggal untuk jenis barang tersebut. Karena muncul motif untuk memaksimumkan keuntungan, dia akan menetapkan harga barang menurut kehendaknya dan menentukan agar penjualan suatu jumlah barang dengan harga tertentu menghasilkan keuntngan bersih yang maksimum.

Satu-satunya cara untuk mengubah harga barang produksinya adalah dengan jalan menambah jumblah hasil bersih dengan cara menjual lebih banyak barang produksinya dalam jumblah pada harga yang lebih rendah, atau menjual barang produksinya yang terbatas dengan haraga yang lebih tinggi. Dengan demikian persoalan penting terletak pada pemilik monopoli yang mempunyai kekuasaan untuk menentukan harga terhadap barang produksinya dan output-nya tergantung pada suatu batas tertentu (berdasarkan motif untuk memaksimumkan keuntungan). Kekuasaan seperti ini tidak terdapat dalam perusahaan yang menjalankan sistem persaingan sempurna. ${ }^{29}$ Suatu yang dingat adalah bahwa haraga yang ditentukn oleh pihak yang menjalankan monopoli jauh lebih tinggi dibandingkan jika dia berada dalam pasar persangan sempurna. $^{30}$

Beberapa Aspek Khusus Pasar Monopoli mencakup:

a. Ciri-ciri pasar monopoli

Ciri-ciri pasar monopoli sangat berbeda dengan pasar persaingan sempurna. Uraian berikut menerangkan ciri-ciri monopoli.

1. Pasar Monopoli Adalah Industri Satu Perusahaan

Hanya ada satu saja perusahaan dalam industri. Dengan demikian barang atau jasa yang dihasilkannya tidak dapat dibeli dari tempat lain. Syarat-syarat penjual sepenuhnya ditentukan oleh monopoli itu, dan para pembeli tidak dapat berbuat suatu apa pun di dalam menentukan syarat jual beli.

2. Tidak Mempunyai Barang Penganti Yang Mirip

${ }^{28}$ Yusuf Al-Qaradhawi, op.cit., h. 190-191

${ }^{29}$ Persaingan sempurana adalah suatu bentuk interaksi antara permintaan dengan penawar di mana jumblah pembeli dan penjual sedemikian rupa banyaknya/tidak terbatas. Lihat Eko Supriyanto, Ekonomi Mikro Perspektif Islam (Cet. 1; Malang:UIN Malang Press, 2008), h. 201.

${ }^{30}$ Muhammad Nejatullah Siddiqi, op.cit., h. 125. 


\section{Tahkím}

Vol. XIV, No. 2, Desember 2018

Artinya barang tersebut satu-satunya jenis barang yang seperti itu dan tidak terdapat barang mirip (close substitusi) yang menggantikan barang tersebut. Aliran listrik merupakan contoh dari barang yang tidak mempunyai barang pengganti yang mirip. Yang ada hanyalah barang penggati yang sangat berbeda sifatnya, lampu minyak. Lampu minyak tidak dapat menggantikan listrik karena, ia tidak dapat menghidupkan televisi.

3. Tidak Terdapat Kemungkinan Untuk Masuk Kedalam Industri

Sifat ini merupakan sebab utama yang menimbulkan perusahaan yang mempunyai kekuasaan monopoli. Tanpa sifat ini tidak akan terwujud, karena tampa adanya halangan tersebut pada akhirnya akan terdapat beberapa perusahaan di dalam indusri. Keuntungan perusahaan monopoli tidak akan menyebabkan perusahaan-perusaan lain memasuki industri tersebut. ${ }^{31}$ Ada beberapa bentuk hambatan masukan ke dalam monopoli yaitu hambatan teknis, (special knowladge, tingginya tingkat efisiensi, kontrol sumber faktor produksi), hambatan legalitas (undang-undang dan hak khusus, hak paten atau hak cipta), penguasaan bahan mentah strategi, terbatasnya pasar, pemberian hak monopoli oleh pemerintah. $^{32}$

4. Dapat Mempengaruhi Penentuan Harga

Karena perusahaan monopoli merupakan satu-satunya penjual di dalam pasar, maka penentu harga dapat dikuasainya. Sebab itu monopoli dipandang penentu harga atau price setter. Dengan mengadakan pengendalian ke atas produksi dan jumbah barang yang ditawarkan perusahaaan monopoli dapat menentukan harga pada tingkat yang di kehendakinya.

5. Promosi Iklan Kurang Diperlukan

Disini perusaaan monopoli tidak perlu mempromosikan barangnya dengan mengunakan iklan. Pembeli yang memerlukan barang yang diproduksinya terpaksa membeli daripadanya. Walau bagaimanapun perusahaan monopoli sering membuat iklan. Iklan tersebut bukanlah bertujuan untuk menarik pembeli, tapi untuk memelihara hubungan baik dengan masyarakat.

Berdasarkan karakter ke empat, monopolis memiliki apa yang disebut sebagai market power, ${ }^{33}$ yaitu kekuatan/kemampuan untuk menentukan harga dari suatu barang di pasar. Sumber-sumber market power yang dimiliki oleh monopolis, dalam hal ini disebut sebagai monopoly power antara lain adalah; (a) elastisitas permintaan pasar, (b) jumlah perusahaan dalam pasar, (c) interaksi perusahaan di dalam pasar.

\footnotetext{
${ }^{31}$ Sandono Sukirno, Mikroekonomi Teori Pengantar (Ed, 1; Jakarta: PT Rajagrafindo Persada, 2005), h. 267.

${ }^{32}$ Eko Suprayitno, op.cit., h. 212.

${ }^{33}$ Merupakan pergeseran permintaann dan penawaran yang tercermin dalam perubahan relatif harganya, dan begitu berperan sebagai petunjuk dan pedoman bagi usaha yang mengambil keputusan untuk melakukan investasi, membeli dan menjual. Lihat Henricus W. Ismanthono, op.cit., h. 192.
} 


\section{Tahkím}

Vol. XIV, No. 2, Desember 2018

Dalam pasar persaingan sempurna, kita mengambarkan kurva untuk perusahaan dan kurva untuk pasar secara keseluruhan secara terpisah. Dalam monopoli hanya diperlukan satu kurva, karena dalam monopoli, perusahaan juga merupakan pasar. Maka kurva permintaan yang dihadapi oleh monopolis (perusahaan) juga identik dengan kurva permintaan pasar. Bentuk kurva permintaan pasar adalah menurun dari kiri ke atas ke kanan ke bawah, artinya monopoli tersebut dapat mempengaruhi harga pasar dengan jalan menjual lebih sedikit atau lebih bayak barang produksinya. ${ }^{34}$

b. Faktor-faktor Yang Menimbulkan Monopoli

Terdapat tiga faktor yang dapat menyebabkan wujudnya pasar (perusahaan) monopoli antara lain adalah.

1. Perusahaan monopoli mempunyai suatu sumber daya tertentu yang unik dan tidak dimiliki oleh perusahaan lain.

Suatu contoh yang jelas dalam hal ini dalah suara emas dari seorang penyayi terkenal atau kemampuan bermain yang sangat luar biasa oelh seorang pemain sepak bola. Hanya mereka yang mempunyai kepandaian tersebut dan harus dibayar lebih mahal dari biasa apabila masyarakat ingin menikmatinya.

Dalam suatu perekonomian, monopoli monopoli dapat berlaku apabila suatu perusahaan menguasai seluruh atau sebagain besar bahan menta yang tersedia. Di masa ini contoh perusahaan yang mempunyai sifat seperti ini adalah perusahaan permata De Beers company di Afrika Selatan. Hampir semua pertambangan permata yang ada di dunia ini di miliki oleh perusahaan tersebut. Pada permulaan abad yang lalu perusahaan Standard Oil Company di Amerika Serikat menguasai hampir seluruh sumber minyak yang ada di negara tersebut. Sampai sebelum Perang Dunia Kedua perusahaan Alumunium Company of America juga mempunyai kekuasaan monopoli. Pada awal itu hampir semua cadangan bauxite, yaitu bahan mentah yang digunakan untuk menghasilkan alumunium, dimiliki oleh perusahaan itu. Oleh karena itu Alumunium Company of America dapat menghasilkan barangnya tampa ada persaingan. Perusahaan air minum di suatu kota adalah contoh lain dari kekuasaan monopoli yang memilki sumber daya yang unik.

2. Perusahaan monopoli pada umumnya dapat menikmati skala ekonomi (economic of scale $)^{35}$ hingga ketingkat produksi yang sangat tinggi.

Pada abad ini perkembangan teknologi berlaku sangat pesat sekali. Di berbagai kegitan ekonomi tingkat teknologi adalah sedemikian moderennya sehingga produksi yang efesien hanya dapat dilakukan apa bila jumlah produksinya sangat besar dan meliputi hampir seluruh produk yang ada di dalam pasar. Keadaan seperti

\footnotetext{
${ }^{34}$ Veithzal Rivai Zainal dkk, Islamic Business Management: Praktek Manajemen Bisnis Yang Sesui Syariah Islam, (Cet. 1; Yogyakarta: BPEF, 2004), h. 260.

${ }^{35}$ Skala ekonomi merupakan skala kapasitas produksi suatu unit; biaya rata-rata yang mengalami penurunan akibat meningkatnya pengeluaran perusahaan ketika seluruh faktor ekonomi dalam keadaan tidak tetap. Lihat Winarno Sigit dan Ismaya Sujana, op.cit., h. 177.
} 


\section{Tahkím}

Vol. XIV, No. 2, Desember 2018

ini berarti suatu perusahaan hanya akan menikmati skala ekonomi yang maksimum apabila tingkat produksinya adalah sangat besar jumlahnya. Pada waktu perusahaan mencapai keadaan di mana biaya mencapai minimum, jumlah produksi adalah hampir menyamai jumlah permintaan yang wujud di pasar. Dengan demikian, sebagai akibat skala eknmomi yang demikian sifatnya, perusahaan dapat menurunkan harga barang apabila produk semakin tinggi. Pada tingkat produksi yang sangat tinggi, harga dalah sedemikian rendahnya sehingga perusahaanperusahaan baru tidak akan sanggup bersaing dengan perusahaan yang lebih dahulu berkembang. Keadaan ini mewujudkan pasar monopoli.

Skala indutri yang memiliki sifat seperti ini adalah perusahaan yang dikatakan merupakan monopoli alamiah atau natural monopoly. ${ }^{36}$ Monopoli alamiah pada umumnya dijumpai dalam jasa umum (utilities ${ }^{37}$ ) seperti perusahaan listrik, perusahaan air minum, perusahaan telepon, dan perusahaan angkutan kereta api. Di beberapa jenis industri lain skala ekonomi tidak mewujudkan monopoli, tapi satu atau beberapa perusahaan memproduksikan barngnaya yag hampir sama jumlahnya dengan yang ditawaran di pasar. Perusahaan baja, pertambangan minyak dan industri pembuatan mobil adalah contoh-contoh dari industri semacam itu.

3. Monopoli wujud dan berkembang memalui undang-undang, yaitu pemerintah memberi hak monopoli kepada kepala perusahaan tersebut.

Dalam undang-undang pemerintah yang mengatur kegatan perusahaan-perusahaan terdapat beberapa peraturan yang akan mewujudkan kekuasaan monopoli. Peraturan yang seperti itu adalah

(1) peraturan paten dan hak cipta (copy right)

hak cipta atau copy right ${ }^{38}$ merupakan bebtuk lain dari hak paten, yaitu ia merupakan suatu jaminan hukum untuk menghindari penjiplakan. Tetapi hak cipta diberikan khusus kepada penulis buku dan penggubah lagu. Dengan adanya hak cipta tersebut hanya penulis atau penggubah lagu saja yang mempunyai hak ke atas penerbit buku ditulis dan laugu yang digubah.

(2) hak usaha eksklusif (exlusive farnchise) yang diberikan kepada jasa umum.

Apa skala diperoleh perusahaan setelah perusahaan itu menciptaka tingkat produksinya yang sangat tinggi, kepentingan khalayak ramai akan dimaksimalkan apabila perusahaan diberi kesmpatan untuk skala ekonomi itu, dan pada waktu yang sama diharuskan menjual produksinya dengan harga produksi yang rendah. Untuk menciptakan keadaan seperti ini secara serentak

\footnotetext{
${ }^{36}$ Sebuah monopoli yang timbul karena keadaan alamiah. Lihat, Winardi, op.cit., h. 360.

${ }^{37}$ Kemampauan suatu benda material atau jasa untuk memenuhi kebutuhan manusia dan berhubungan dengan istilah public utility. Lihat ibid., h. 516.

${ }^{38}$ Hak eksklusif yang diberikan pemerinta kepada pencipta karya sastra atau seni seperti buku, peta artikel, gambar, foto, komposisi musik, film, rekaman atau progra komputer. Hak ekslusif ini diberikan untuk jangka tertentu. Lihat Ismanthono W. Henricu, Kamus Istilah Ekonomi Dan Bisnis, h. 68.
} 


\section{Tahkím}

Vol. XIV, No. 2, Desember 2018

pemerintah harus menjalankan dua langkah: (i) memberikan hak monopoli kepada suatu perusahaan dalam suatu kegiatan tertentu, dan (i) menentukan harga/tarif yang rendah atas barang/jasa yang diproduksi. Contoh perusahaan seperti ini adalah perusahaan air minum, perusahaan pembangkit listrik dan angkutan kereta api.

Tampa adanya hak eksklusif untuk berusaha sebagai perusahaan monopoli akan timbul halangan untuk menikmati skala ekonomi secara maksimum. Sebagai akibatnya perusahaan akan menetapkan harga/tarif yang tinggi atas barang/jasa yang dihasilkan. Keadaan seperti ini akan menimbulkan kerugian kepada masyarakat, karena mereka harus membayar produksi perusahaan itu dengan harga yang tinggi.

Status penjual sebagai monopolis sangat relatif tergantung tepat, barang subtitusi, dan waktu. Seorang penjual dapat sebagai monopolis dalam satu Desa tetapi tidak bisa lagi mencangkup ke Kecamatan. Pabrik Semen Gresik sebagai monopoli di Jawa Timur, tetapi tidak untuk indonesia perlu dicatat juga meskipun Semen Gresik adalah satu-satunya di Jawa Timur, tetapi jika merk semen lain dapat leluasa masuk di Jawa Timur.

Selain itu, adanya barang substitusi yang dekat akan mengurangi atau bahkan akan melunturkan status monopoli dari suatu barang. PT. Persero Kereta Api Indonesia (PT. KAI) adalah monopoli dalam pelayanan dalam jasa kereta api. Akan tetetapi jasa penggantinya ada, yaitu bus, kapal laut, dan pesawat udara. Dengan adanya barang substitusi, maka dengan sendirinya market power akan semakin berkurang. Oleh sebab itu, status monopoli sebuah barang akan tergantung bagaimana mendefenisikan barang itu. Seperti contoh tadi, untuk jasa angkutan kereta api PT. KAI memegang hak monopoli, tetapi untuk jasa angkutan dalam arti yang lebih luas PT. KAI bukan lagi sebagai monopolis.

Contoh lainnya adalah AQUA. Pada mula-mula munculnya air mineral, AQUA adalah satu-satunya produsen, namun beberapa tahun kemudia bermunculan merk-merk lain seperti ADES, CLUB, LE MINERALE dan lain-lain. ${ }^{39}$ Adapun kasus tentang KKPU disebut AQUA memonopoli usaha AMDK. Berita ini diakses lewat jawapos.Com bahwa:

Komisi Pengawas Persaingan Usaha (KPPU) menyimpulkan PT Tirta Investama selaku produsen air minum dalam kemasan (AMDK) merek Aqua melakukan monopoli usaha. Tidak hanya itu, KPPU juga menyatakan tindakan PT Tirta Investama dilakukan bersama-sama dengan PT Balina Agung Perkasa (distributor tunggal aqua). Tim Investigator KPPU Helmi Nurjamil mengungkapkan, perkara dengan nomor 22/KPPU-L/2016 secara meyakinkan bahwa PT Tirta Investama dan PT Balina Agung Perkasa terbukti bersalah dengan bukti-bukti yang sangat kuat. Adapun

${ }^{39}$ Burhan M. Umar, op.cit., h..190-191. 


\section{Tahkím}

Vol. XIV, No. 2, Desember 2018

bukti-bukti pelanggaran yang dilakukan oleh PT Tirta Investama dan PT Balina Agung Perkasa yakni, telah mendegredasi Toko Cuncun milik Yatim Agus Prasetyo dari status super outlet (SO) menjadi whole seller (WS). Degradasi tersebut bukan berdasarkan performa penjualan, tetapi karena menjual produk pesaing.

Selain itu terbukti terdapat keterlibatan karyawan lebih dari satu orang, dari KAE (Key Account Executive) Area Sales Manager, Regional Sales manager dan sampai tingkat Direktur Utama," papar Helmi Nurjamil kepada wartawan di Jakarta, Jumat (10/11). Dia menyebut, kesimpulan itu telah disampaikan majelis hakim KPPU di hadapan pihak produsen dan distributor Aqua kantor KPPU Jakarta Pusat, pada Selasa (7/11) lalu.

Lebih jauh Helmi Nurjamil menjelaskan, Tim Investigator juga menemukan bukti pelanggaran berupa komunikasi melalui telepon dan WhatsApp, Koordinasi untuk tidak memberi harga khusus kepada SO yang menjual Le Minerale. Juga terdapat bukti prosedur degradasai, bukti form sosialisasi kesetiaan kepada Aqua, terdapat bukti form sosialisasi ke toko-toko. Toko-toko tersebut diminta menandatangani komitmen untuk tidak menjual produk Le Minerale yang merupakan produk AMDK lainnya. "Menurut Saksi Ahli Siti Anisah, tindakan anti kompetitif, menghimbau saja tidak boleh. Apalagi sampai melarang," papar helmi Nurjamil.

Kepala Tim Investigator KPPU Arnold Sihombing menambahkan, berdasarkan bukti-bukti yang telah disampaikan tim Investigator, disimpulakn PT Tirta Investama dan PT Balina Agung Perkasa terbukti telah melanggar pasal 15 ayat 3 huruf $b$ dan pasal 19 huruf a dan $b^{40}$

Dalam Skripsi yang ditulis oleh Alif Nur Hidayati berjudul Tinjauan Yuridis Terhadap Monopoli Perdangan Telkomsel (Studi Putusan No. 496 K/Pdt.Sus/2008) dijelaskan bahwa PT. Telkomsel merupakan perusahaan penyedia jasa layaan selular terbesar di indonesia. Cakupan layanan PT. Telkomsel mencapai 100\% dari keseluruhan Kabupaten di Indonesia dan hampir 40\% dari seluruh Kecamatan di Indonesia. Market power yang dimilki oleh perusahaan tersebut dimanfaatkan untuk melakukan price leadership ${ }^{41}$ dan menerapkan tarif secara eksesif. Tindakan tersebut mengakibatkan kerugian konsumen senilai 9,8 milyar rupiah sampai 24 milyar rupiah atas tindakannya, PT. Telkomsel dijerat dengan pasal 17 ayat (1) UU No. 5 Tahun 1999 Tentang Laragan Praktek Monopoli Dan Persaingan Usaha Tidak Sehat. Atas dasar tersebut Makamah Agung mengelurkan putusan temasek holdings dan praktik monopoli PT. Yang isinya menghukum PT. Telkomsel untuk membayar denda sebesar 15 milyar rupiah. Dari permasalahan tersebut. ${ }^{42}$

\footnotetext{
${ }^{40}$ https://www.jawapos.com/read/2017/11/10/167751/kppu-sebut-aqua-memonopoli-usahaamdk, (diakses 6 Maret 2018).

${ }^{41}$ Merupakan salah satu produser yang menjadi penentu harga dalam industri-industri yang menghasilkan produk yang hampir serupa. Lihat, ibid., h, 127-128.

${ }^{42}$ Hadayati Alif Nur, op.cit., 2017, h. ii.
} 


\section{Tahkím}

Vol. XIV, No. 2, Desember 2018

Dalam perkara praktik monopoli oleh Telkomsel ini, Telkomsel merupakan badan hukum yang didirikan di Indonesia, di Jakarta lebih tepatnya dan berkedudukan di indonesia. Telkomsel melakukan kegiatan usaha bidang ekonomi , tepatnya usaha bidang telekomunikasi. Telkomsel melakukan penguasaan pasar, yaitu mengenai tentang pemahaman pasal 17 ayat (1) tidak bisa lepas dari pasal selanjutnya yakni pasal 17 ayat (2), menyebutkan bahwa suatu pelaku usaha patut diduga atau diangkap telah melakukan penguasaan atas produksi dan/atau pemasaran barang dan/atau jasa apabila:

1. barang dan atau jasa yang bersangkutan belum ada substitusinya ${ }^{43}$

pada kasus ini, unsur "belum ada substitusinya" tidak terpenuhi, karena pada kenyataannya di Indonesia sudah ada beberapa operator selular lain yang di antaranya Indosat, dan XL

2. Mengakibatkan pelaku usaha ain tidak dapat masauk ke dalam persaingan usaha barang dan atau jasa yang sama.

Adanya EBITDA atau pendapatan yang tinggi pada periode cross ownership (2003-2006) telkomsel selalu berda di atas 50\% menunjukan bahwa penyedia jasa layanan selular tersebut memiliki market power yang cukup besar. Hal ini dapat dilihat dari EBITDA masing-masing operator.

\begin{tabular}{|c|c|c|c|}
\hline Tahun & Telkomsel & Indosat & XL \\
\hline 2001 & $71,14 \%$ & $55,32 \%$ & $67,40 \%$ \\
\hline 2002 & $67,48 \%$ & $54,11 \%$ & $67,44 \%$ \\
\hline 2003 & $72,01 \%$ & $53,29 \%$ & $65,34 \%$ \\
\hline 2004 & $72,28 \%$ & $57,69 \%$ & $62,71 \%$ \\
\hline 2005 & $72,91 \%$ & $58,09 \%$ & $56,67 \%$ \\
\hline 2006 & $71,15 \%$ & $57,62 \%$ & $54,17 \%$ \\
\hline $\begin{array}{c}\text { Rata-rata pada periode } \\
\text { cross ownership }\end{array}$ & $72,09 \%$ & $56,67 \%$ & $59,72 \%$ \\
\hline
\end{tabular}

Sumber: Olah data Laporan Keuangan Telkomsel, Indosat, XL, 2018

Market power yang dimilki oleh Telkomsel dimanfaatkan untuk memperoleh keuntungan dengan jumlah yang melebihi dukali lipat. Di samping itu, Telkomsel juga memanfaatkan kesempatan tersebut untuk menghambat persaingannya di pasar bersangkutan. Tindakan tersebut menjadi salah satu faktor yang dapat menurunkan tingkat derajat kompetisi.

Bagi operator baru yanag akan memasuki pasar, Telkomsel memberikan syarat agar operator baru tersebut memenuhi traffic sebesar 48 erl. Salain itu, Telkomsel juga mensyaratkan dalam pembangunan link interkoneksi diharuskan mengunakan pihak

${ }^{43}$ Barang-barang yang saling bersaing karena pembeli bisa beralih ke barang-barang lainya sebagai penganti (substitusi) apa bila terjadi perubahan harga, kualitas ataupun bentuk dari barang yang digunakan selama ini. Ibid., h. 266. 


\section{Tahkím}

Vol. XIV, No. 2, Desember 2018

ketiga yang telah ditunjuk oleh telkomsel. Pada akhirnya, kepemilkikan dan pengoperasian link tersebut bukan menjadi milik pencari inter koneksi, melainkan menjadi milik pihak ketiga dan Telkomsel.

Dalam hal ini operator pencari interkoneksi tidak memiliki posisi tawar yang seimbang dengan telkomsel, sehingga harus mengikuti kehendak Telkomsel dengan ancaman pemutusan hubungan interkoneksi. Hambatan tersebut ditemukan dalam dokumen perjanjian antara Telkomsel dengan salah satu operator tentang interkoneksi. Dokumen perjanjian tersebut mengatur mengenai interkonektor dan pengaturan tarif SMS agar tidak lebih rendah dari harga yang telah ditetapkan oleh Telkomsel.

Meskipun pada akhirnya perjanjian tersebut batal, akan tetapi hal ter sebut telah menunjukan bahwa Telkomsel telah memnfaatkan market power untuk menghambat masuknya persaingan dan pengaturan harga SMS.

3. Satu pelaku usaha atau satu kelompok pelaku usaha menguasai lebih dari $50 \%$ pangsa pasar atau jenis barang atau jasa tertentu. ${ }^{44}$

Tabel

\begin{tabular}{|c|c|c|c|}
\hline Tahun & Telkomsel & Indosat & XL \\
\hline 2001 & $56,14 \%$ & $20,20 \%$ & $23,66 \%$ \\
\hline 2002 & $58,37 \%$ & $25,22 \%$ & $16,42 \%$ \\
\hline 2003 & $60,37 \%$ & $27,72 \%$ & $11,91 \%$ \\
\hline 2004 & $59,93 \%$ & $29,80 \%$ & $10,26 \%$ \\
\hline 2005 & $64,56 \%$ & $26,41 \%$ & $9,03 \%$ \\
\hline 2006 & $68,08 \%$ & $21,55 \%$ & $10,36 \%$ \\
\hline Rata-rata & $\mathbf{6 1 , 4 2 \%}$ & $\mathbf{2 5 , 1 5 \%}$ & $\mathbf{1 3 , 6 1 \%}$ \\
\hline
\end{tabular}

Berdasarkan data yang diperoleh dari LHPL, dapat diketahui bahwa dalam kurun waktu 2001-2006, Telkomsel memiliki rata-rata pangsa pasar sebesar 61,24\%. Rata-rata tersebut telah melebihi batas yang telah ditentukan oleh UU Atimonopoli yakni 50\%. Dengan demikian maka unsur menguasai pasar lebih dari 50\% telah terpenuhu. $^{45}$

c. Kebaikan dan Keburukan Monopoli

Implikasi terhadap kesejateraan masyarakat yang perlu diperhatikan adalah bahwa dalam pasar monopoli:

a. Hilang atau berkurangnya tingkat kesejahteraan konsumen, hal ini terjadi karena volume produksi lebih kecil dari volume output yang optimum, inefesiensi ini menimbulkan kesejateraan masyarakat konsumen semakin berkurang.

\footnotetext{
${ }^{44}$ T.S.C Kansil. dan Kansil Christine S.T., op.cit., h. 197-198.

${ }^{45}$ Hadayati Alif Nur, Skripsi, Tinjauan Yuridis Terhadap Monopoli Perdagangan Telkomsel: Studi Putusan No. 496 K/Pdt. Sus/2008, h. 112-116.
} 


\section{Tahkím}

Vol. XIV, No. 2, Desember 2018

b. Menimbulkan eksploitasi terhadap konsumen dan pemiliki faktor produksi. Konsumen dirugikan karena harga jual di atas harga keseimbangan yang seharusnya terjadi bila berdasarkan mekanisme pasar. Sedankan bagi pemilik faktor produksi dirugikan oleh dengan dibayarnya faktor produksi dengan harga yang lebih rendah dari nilai pasar dari output yang dihasilkan

c. Buruknya makro ekonomi nasional, sebab jumlah output riil industri lebih sedkit daripada kemampuan sebenarnya. Karena tidak seluruh faktor produksi terpakai sesui dengan kapasitas produksi maka akan menimbulkan pengaguran maupun faktor-faktor produksi lainnya.

d. Memburuknya perekonomian internasional, hal ini terjadi karena inefiensi. Sebab sesuai dengan tuntutan dalam perdagangan bebas di mana efisiensi adalah faktor penentu. Maka monopoli yang menimbulkan inefiensi buruk bagi kondisi perekonomian internasional.

Ada beberapa kebijakan yang ditempuh pemerintah untuk mengurangi efek negatif pemerintah:

a. Melalui penetapan Undang-Undang anti-trust.

b. Pemerintah memdirikan perusahaan tandingan di dalam pasar tersebut dengan tujuan untuk memberi persaingan kepada si monopolis untuk membatasai membatasi kekuasaan monopolisnya.

c. Membuka kran impor sehingga barang buatan luar negeri bisa memberikan persaingan kepada barang dalam negeri.

d. Dengan membuat ketentuan khusus terhadap operasi perusahaan monopoli tersebut, misalnya dengan menetapkan harga yang seharusnya di bawa harga monopolis, atau dengan penetapan tingkat output yang optimum bagi masyarakat. Dapat pula dengan mengenakan pajak kepada monopolis. ${ }^{46}$

Pemerintah dalam mengatur penetapan harga yang maksimal bisa dilihat pada gambar di bawah ini:

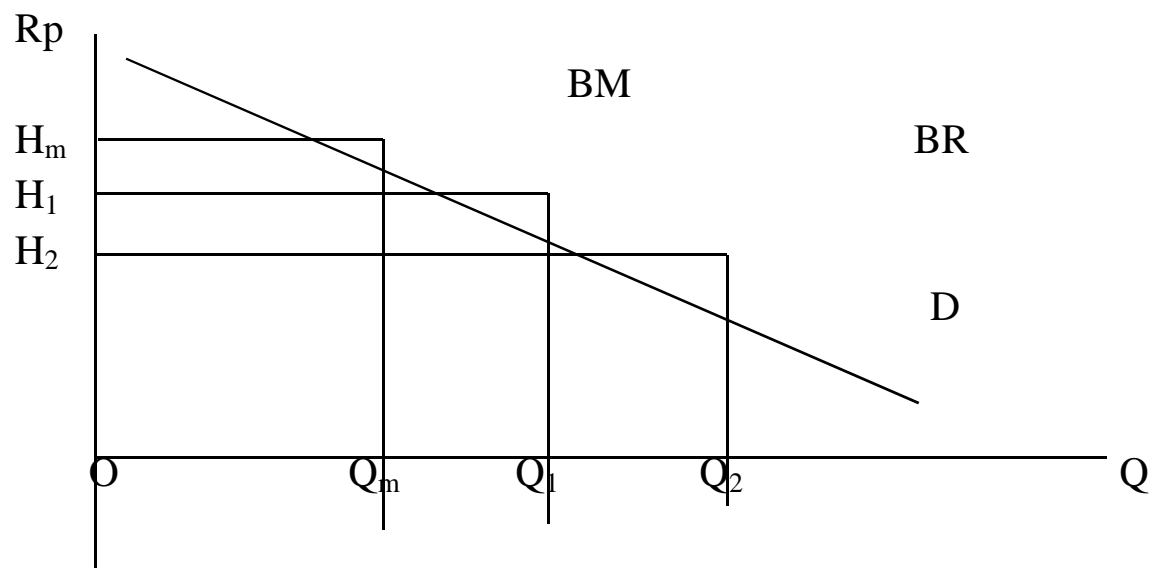

${ }^{46}$ Nur Rianto Al-Arif dan Euis Amalia,Teori Mikroekonomi: Suatu Perbandingan Ekonomi Islam dan Ekonomi Konvensional, (Cet. 3; Jakarta: Kencana, 2016), h. 240-241. 


\section{Tahkím}

Vol. XIV, No. 2, Desember 2018

Menunjukan dua buah kemungkinan (diantara banyak kemungkinan pemerintah bila menguasa monopoli (pengusaha yang memegang kekuasan monopoli) akan menetapkan harga $\mathrm{H}_{\mathrm{m}}$ dan menjual sebanyak $\mathrm{OQ}_{\mathrm{m}}$. Pemerintah dapat menetapkan harga patokan setinggi $\mathrm{OH}_{1}=$ biaya marginal dan pengusaha masih memperoleh keuntungan di atas normal. Harga menjadi lebih rendah dan kualitas yang dijual lebih banyak. Kesejahteraan konsumen diperbesar dengan makin besarnya surplus konsumen dan makin besarnya persediaan barang di pasar yang mampu dibelinya. Disamping itu perluasan produksi akan memperluas kesempatan kerja. Apa bila perusahaan ini dikuasai oleh pemerintah (perum, perjan atau persero) pemerintah mungkin menetapkan harga patokan $\mathrm{H}_{2}=$ biaya rata-rata. ${ }^{47}$

Tetapi monopoli tidak selalu lebih buruk daripada persaingan sempurna, yaitu bila kita lihat dari segi lain:

a. Monopoli mendorong perusahaan untuk melakukan inovasi baru dalam produknya. Sebab keuntungan monopoli yang didapatkan oleh mereka digunakan untuk tujuan penelitian dan pengembangan. Seperti yang dikemukakan oleh Josep Schumpetet bahwa faktor pengusaha yang cenderung untuk selalu melakukan inovasilah yang mendorong pertumbuhan menjadi lebih baik.

b. Dalam kasus monopoli alamiah, di mana luas pasar terbatas dan skala ekonomis yang besar, maka sangat tidak efisien bila diharapkan dalam bentuk industri persaingan sempurna. Sebab bila dilakukan yang terjadi justru banyak timbulnya perusahaan kecil, dimana masing-masing perusahaan kecil ini tidak bisa memanfaatkan skala ekonomis yang besar, hal ini akan menyebabkan industri akan menjadi tidak efisien ${ }^{48}$

Selain pemerintah yang berperan mengawasi praktek monopoli, ada juga Komisi Pengawasan Persaingan Usaha (KPPU). Komisi ini adalah suatu lembaga independen yang terlepas dari pengaruh kekuasaan pemerintah serta pihak lain. Adapun yang menjadi tugas komisi dapat di simpulkan sebagai berikut:

1. Melakukan penilain terhadapat perjanjian yang dapat mengakibatkan terjadinya praktek monopoli/atau persaingan usaha tidak sehat.

2. Melakukan penilaian terhadap kegiatan usaha dan tindakan pelaku usaha yang dapat mengakibatkan terjadinya praktek monopoli dan atau persaingan usaha tidak sehat.

3. Melakukan penilaian terhadap ada tidaknya penyalah gunaan posisi dominan yang dapat mengakibatkan terjadinya praktek monopoli dan atau persaingan tidak sehat.

4. Mengambil tindakan sesuai dengan wewenang komisi.

5. Memberikan saran dan pertimbangan terhadap kebijakan Pemerintah yang berkaitan dengan praktek monopoli da atau persaingan usaha tidak sehat.

6. Menyusun pedoman dan atau publikasi yang berkaitan dengan Undang-Undang ini.

\footnotetext{
${ }^{47}$ Sudarsono, Pengantar Ekonomi Mikro, (Cet. 8, Ed. Revisi; Jakarta: LP3ES, 1995), h. 295-296.

${ }^{48}$ Nur Rianto Al-Arif dan Euis Amalia, op.cit., h. 241.
} 


\section{Tahkím}

Vol. XIV, No. 2, Desember 2018

7. Memberikan laporan secara berkala atas hasil kerja komisi kepada Presiden dan Dewan Perwakilan Rakyat. ${ }^{49}$

\section{Monopoli Perspektif Islam}

Secara sunnatullah setiap perusahaan termasuk perusahaan monopoli akan berlaku hukum pertambahan hasil yang berkurang (law of diminishing return), artinya dalam jumlah produksi produksi tertentu perusahaan masih mengalami keuntungan, akan tetapi manakala produksi telah mencaai titik maksimal maka hasilnya yang diperoleh justru akan meurun. Oleh karena itu harga barang di pasar atau perusahaan mobopoli dapat dipastikan selalu lebih tinggi. ${ }^{50}$ Dalam hal ini penulis telah menulis defenisi-defenisi monopoli menurut para ulama dan tokoh ekonomi di atas.

Jika semangat Islam masuk maka akan mempengaruhi orang-orang yang menjalankan monopoli tersebut. Dia akan menurunkan harga karena kini dia akan puas dengan keuntungan yang mencukupi dibandingkan dengan sebelunya yang merupakan keuntungan yang semaksimum mungkin. Tetapi jika monopoli terpaksa mengeluarkan barang-barang produksinya dengan harga yang cukup tinggi, harga tersebut tidak akan turun sebagaimana yang terdapat dalam pasar persaingan sempurna. Monopoli diperkirakan akan puas dengan kadar keuntungan yang lebih rendah karena ia merupakan penjual yang besar yang sudah tentu akan mendapatkan keuntungan yang besar dari barang-barang produksinya. Dengan asumsi bahwa kepatuhan terhadap prinsip islam yang menyerukan umatnya untuk melakukan kebajikan dan menjunjung tinggi pelayanan kepada masyarakat akan terjadi, maka monopoli akan mencapai beberapa kebaikan yang tidak didapat oleh perusahan dalam persaingan sempurna. ${ }^{51}$

Dalam Islam pun boleh berbisnis tanpa peduli apakah dia satu-satunya penjual (monopoli) atau ada penjual lain. Menyimpan barang untuk keperluan persediaan pun tidak dilarang dalam Islam. Yang dilarang itu adalah ihtikar yaitu mengambil keuntungan di atas keuntungan normal dengan cara menjual barang lebih sedikit untuk mendapatkan harga yang lebih tinggi. Atau istilah ekonominya monopoly's rent tidak boleh. Jadi, dalam Islam, monopoli boleh, sedangkan monopoly's rent tidak boleh.

Menurut Imam al-Gazali, ada 3 syarat ihtikar yakni: (a) objek penimbunan merupakan barang-barang kebutuhan masyarakat, (b) waktu penimbunan adalah pada waktu persediaan bahan makanan sangat sedikit, atau dapat dikatakan pada masa paceklik. (c) tujuan penimbunan adalah untuk meraih keuntungan diatas keuntungan keuntungan normal. Sehingga tindakan untuk menyimpan barang untuk keperluan persediaan tidak dilarang.

Sedangkan menurut Adiwarman Karim, suatu kegiatan masuk dalam kategori ihtikar apabila terpenuhinya syarat-syarat:

\footnotetext{
${ }^{49}$ Burhanudin S., op.cit., h. 239-240.

${ }^{50}$ Ibid., h. 242.

${ }^{51}$ Muhammad Neiatullah Siddiqi, op.cit., h. 127-128.
} 


\section{Tahkím}

Vol. XIV, No. 2, Desember 2018

a) Mengupayakan adanya kelangkaan barang, baik dengan cara menimbun stok atau mengenakan hambatan masuk kepada perusahaan lain untuk masuk kedalam pasar (entry barries)

b) Menjual dengan harga yang lebih tinggi dibandingkan dengan harga sebelum munculnya kelangkaan.

c) Mengambil keuntungan yang lebih tinggi di bandingkan keuntungan sebelumnya syarat 1 dan 2 dilakukan.

Pandangan ekonomi Islam terfokus pada masalah mekanisme penentuan harga yang didalam monopoli (dengan ihtikar) yang cenderung berpotensi merugikan konsumen di satu pihak dan menguntungkan produsen di pihak lain. Sebab harga ditentukan lebih berorientasi kepada kepentingan produsen saja. Dalam ajaran Islam, meskipun keuntungan yang dihasilkan tanpa melakukan ihtikar lebih sedikit, tetapi keuntungan yang mencerminkan keadilan baik untuk penjual (produsen) maupun untuk pembeli (konsumen), atau dengan kata lain harga harus mencerminkan keadilan baik dari sisi produsen maupun konsumen, selain keadalian, parameter etis yang membedakan ajaran ekonomi Islam dan ekonomi konvensional adalah kesederhanaan, dan persaudaraan. ${ }^{52}$

\section{Kesimpulan}

Monopoli adalah penguasaan pasar oleh satu perusahaan atau kelompok perusahaan besar, di mana terdapat hambatan bagi perusahaan lain untuk masuk. Monopoli dapat ditimbulkan oleh faktor teknis dan legalitas. Secara jangka pendek umumnya monopoli mendapat keuntungan, namun bukan berarti monopoli tidak mendapat kerugian. Dalam jangka panjang monopoli tidak mendapat masalah sama sekali karena bila mendapat keuntungan. Akan tetapi jika ada dalam jangka pendek ada perusahan lain masuk atau ada barang sejenis penggantinya maka dia tidak bisa disebut lagi monopoli. Monopoli itu dalam artian sejauh mana dia menguasai suatu wilayah dan mempengaruhi konsumen.

Dalam struktur pasar monopoli mempunyai beberapa kelemahan, bukan berarti selamanya buruk, ada sisi baik dalam monopoli. Dalam pandangan Islam monopoli merupakan sesuatu yang sah. Yang tidak diperbolehkan dalam Islam adalah perilaku monopolis yang dapat merugikan masyarakat. Tidak semua orang dapat melakukan monopoli hanya orang-orang tertentu saja yang mempunyai modal dan kekuatan yang besar.

\footnotetext{
${ }^{52}$ Zainal Veithzal Rivai, dkk., op.cit., h. 261.
} 


\section{Tahkím}

Vol. XIV, No. 2, Desember 2018

\section{DAFTAR PUSTAKA}

Ali, Mauludi. "Pasar Bebas Dalam Perspektif Ekonomi Islam," Jurnal Ahkam Hukum Islam, Vol. 1 No. 1, 2013.

Al-Arif Nur Rianto, dan Euis Amalia. Teori Mikroekonomi: Suatu Perbandingan Ekonomi Islam dan Ekonomi Konvensional, Cet. III, Jakarta: Kencana, 2016.

Al-Haritsi, Jaribah bin Ahmad. Fikih Umar Bin Al-Khathab, Cet. 1; Jakarta Timur, Pustaka Al-Kautsar, 2006.

Al-Qaradhawi, Yusuf. Norma dan Etika Ekonomi Islam, Cet. 1; Jakarta: Gema Insani, 1997.

Badudu, J.S dan Muhammad Zain Sultan. Kamus Umum Bahasa Indonesi, Jakarta: Pustaka Sinar Harapan, 1994.

Burhan, M. Umar. Konsep Dasar Teori Ekonomi Mikro: Disertai Contoh-Contoh Soal dan Penyelesainanya, Cet. 1; Malang: Badan Penerbit Fakultas Ekonomi Brawijaya, 2006.

Chapra, M. Umer. Islam dan Tantangan Ekonomi, Cet. 1; Jakarta: Gema Insani Press, 2000.

Hatta, Muhammad. Satu Abad Bung Hata: Demokrasi Kita, Bebas Aktif, Ekonomi Masa Depan, Jakarta: UI Press, 2006.

Ibnu Katsir, Terjemahan Singkat Tafsir Ibu Kasir, Ed. Revisi, Surabaya: PT. Bina Ilmu, 2012.

Ibnu Khaldun. Mukaddimah: Sebuah Karya Mega-Fenomenal dari Cendikiawan Muslim Abad Pertengaha, Cet. 1; Jakarta: Pustaka Al-Kausar, 2011.

Ismanthono W. Henricus, Kamus istilah Ekonomi dan Bisnis, Jakarta: Kompas, 2010.

Kansil, T.S.C dan Kansil Christine S.T., Pokok-Pokok Pengetahuan Hukum Dagang Indonesia,Cet. 3; Jakarta: Sinar Grafik, 2006.

Karim, Adiwarman A. Ekonomi Mikro Islam, Cet. 4, Ed. 3; Jakarta, Rajawali Pers, 2011.

Mannan, M. Abdul. Teori dan Praktek Ekonomi Islam, Yogyakarta: PT. Dana Bakti Wakaf, 1995.

Al-Mundziri, Imam. Ringkasan Shahih Muslim, Cet. 4; Bandung: Jabal, 2016.

Nur, Hadayati Alif. Skripsi Tinjauan Yuridis Terhadap Monopoli Perdagangan Telkomsel: Studi Putusan No. 496 K/Pdt. Sus/2008,UIN sunan kalijaga yogyakarta, 2017.

Rozalinda. Ekonomi Islam: Teori dan Aplikasinya Pada Aktivitas Ekonomi, Cet. 3, Ed. 1; Jakarta: Rajawali Pers, 2016.

------. Fikih Ekonomi Syariah: Prinsip dan Implementasinya Pada Sektor Keuangan Syariah, Cet. 2, Ed. 1; Jakarta: Rajawali Pers, 2017. 


\section{Tahkím}

Vol. XIV, No. 2, Desember 2018

S., Burhanuddin. Hukum Bisnis Syariah, Cet. 1; Yogyakarta: UII Press, 2011.

Siddiqi, Muhammad Nejatullah, Kegiatan Ekonomi Dalam Islam, Cet. 1; Jakarta: Bumi Aksara, 1991.

Sudarsono. Pengantar Ekonomi Mikro, Cet. 8, Ed. Revisi; Jakarta: LP3ES, 1995.

Sukirno, Sadono, Mikroekonomi Teori Pengantar, Ed, 1; Jakarta: PT Rajagrafindo Persada, 2005.

Suprayitno, Eko. Ekonomo Mikro Perspektif Islam, Cet. 1; Malang:UIN Malang Press, 2008.

Sharif, Chaudhy Muhammad. Sistem Ekonomi Islam: Prinsip Dasar, Cet. 3, Ed. 1; Jakarta: Kencana, 2016.

Al-Thabari. Tafsir Ath-Thabari, Surah Al-Baqarah, Jilid 4, Cet. 1; Jakarta: Pustaka Azzam, 20008.

Tarmizi, Ewandi, Harta Haram Muamalat Kontemporer, Cet. 16; Bogor: Berkat Mulia Insani, 2017.

Triyanta, Agus. Hukum Ekonomi Islam: Dari Politik Hukum Ekonomi Islam Sampai Pranata Ekonomi Syariah, Cet. 1; Yogyakarta: FH UII Press, 2012.

Winardi, kamus ekonomi: inggris-indonesia, Cet. XVII, Bandung: Sumber Sari Indah, 2011.

Sigit, Winarno dan Ismaya Sujana. Kamus Besar Ekonomi, Cet. 3; Bandung: Pustaka Grafik, 2010.

Zainal, Veithzal Rivai, dkk. Islamic Business Management: Praktek Manajemen Bisnis Yang Sesui Syariah Islam, Cet. 1; Yogyakarta: BPEF, 2004.

Internet:

https://www.jawapos.com/read/2017/11/10/167751/kppu-sebut-aqua-memonopoliusaha-amdk, di Akses 6 Maret 2018, Yogyakarta. 